ARTIKEL PENELITIAN

\title{
UJI EFEKTIVITAS ANTIBIOTIK EKSTRAK DAUN BELIMBING WULUH (Averrhoa bilimbi L.) TERHADAP PERTUMBUHAN Staphyloccus aureus SECARA IN VITRO
}

\author{
Dhifo Indratama ${ }^{1}$ Yenita $^{2}$ \\ ${ }^{1}$ Fakultas Kedokteran Universitas Muhammadiyah Sumatera Utara \\ ${ }^{2}$ Bagian Farmakologi, Fakultas Kedokteran, Universitas Muhammadiyah Sumatera Utara
}

\begin{abstract}
Infection is the most common disease in Indonesia. Infection diseases are caused by microorganisms such as the Staphylococcus aureus. While in fact, many plants can be used as traditional medicine, one of those is the leaves of belimbing wuluh tree (Averrhoa bilimbi L.) This study aims to determine the inhibitory power of leaves of Cucumber tree_(Averrhoa bilimbi L.) on growth of Staphylococcus aureus in vitro. This study used an experimental method. The technique used to measure antibiotic activity is the method of disk diffusion and continued by Kruskal-Wallis test and Mann-Whitney test. Leaves of belimbing wuluh tree (Averrhoa bilimbi L.) at concentrations of 40\%, 60\%, $80 \%, 100 \%$, amoksisilin, and aquabidest resulted in average diameter of clear zone. leaves of belimbing wuluh tree (Averrhoa bilimbi L.) have an inhibitory power against Staphylococcus aureus.
\end{abstract}

Keywords: Leaves of belimbing wuluh tree (Averrhoa bilimbi L.), Staphylococcus aureus.

\section{PENDAHULUAN}

Penyakit infeksi merupakan penyakit terbanyak di Indonesia. Penyakit infeksi dapat menular dari satu orang ke orang yang lain atau dari hewan ke manusia yang disebabkan beberapa mikroorganisme seperti bakteri, virus, parasit, dan jamur. ${ }^{1}$

Mikroba yang menyebabkan infeksi salah satunya bakteri Staphylococcus aureus. Bakteri ini umumnya ada di udara, debu, limbah, tumbuh pada makanan dan menghasilkan enterotoksin tetapi tidak mempengaruhi bentuk luar makanan tersebut. Gejala yang sering ditimbulkan oleh Staphylococcus aureus biasnaya demam, mual, muntah, diare dan ruam pada kulit. ${ }^{2}$
Penyakit infeksi merupakan penyakit penyebab kematian pada anakanak maupun dewasa dengan lebih dari 13 juta jiwa setiap tahunya, WHO melaporkan bahwa penyakit infeksi menempati urutan kedua (25\%) setelah kematian yang disebabkan oleh penyakit kardiovaskular. ${ }^{3}$ Prevalensi penyakit infeksi di Timur tengah yaitu sebesar $11,8 \%$. Sedangkan di Asia Tenggara prevalensinya cukup bervariasi, yaitu di Thailand 33,5\%, Singapura 13\%, dan di Indonesia sebesar $23,5 \%{ }^{4}$

Di zaman modern ini infeksi bakteri menjadi salah satu penyebab infeksi paling sering dijumpai, sehingga penggunaan antibiotik adalah hal yang paling tepat dalam mengatasi infeksi. ${ }^{5}$ Sekitar $40-62 \%$ antibiotik digunakan secara tidak tepat sehingga muncul 
berbagai macam Multi Drug Resistance Organisme (MDROs) sehingga antibiotik tidak sensitive lagi terhadap bakteri. $^{5,6}$

Banyak tanaman yang dapat digunakan sebagai obat tradisional untuk mengatasi berbagai penyakit termasuk infeksi, karena banyak orang beranggapan bahwa penggunaan obat tradisional relatif lebih aman dibandingkan bahan kimia. Salah satu diantara adalah tanaman yang dapat digunakan sebagai obat adalah belimbing wuluh (Averrhoa bilimbi L.). ${ }^{7}$

Menururt penelitian, karakteristik fisik-kimia dan aktivitas antibakteri ektrak buah belimbing wuluh (Averrhoa bilimbi L.) dengan metode maserasi. Penelitian mengguanakn rancangan acak kelompok (RAK) sebanyak 2 faktor. Faktor pertama yaitu pelarut berbahan etanol 70\%) dan faktor kedua yaitu rasio bahan : pelarut $\mathrm{b} / \mathrm{v})(1: 4 ; 1: 5 ; 1: 6)$ diulang 3 kali. Hasilnya perlakuan jenis pelarut yang berbeda memberikan pengaruh yang berbeda nyata $(\mathrm{a}=0.05)$ terhadap rendemen, total fenol, dan aktivitas antibakteri terhadap bakteri Staphylococcus aureus dan Escherichia coli. Pemberian rasio bahan:pelarut (b/v) yang berbeda memberikan pengaruh yang berbeda nyata $(\mathrm{a}=0.05)$ terhadap rendemen ekstrak daun belimbing wuluh. $^{8}$

\section{METODE PENELITIAN}

\section{Jenis penelitian}

Penelitian ini bersifat eksperimental dengan rancangan penelitian menggunakan 6 kelompok sebagai objek di antaranya kelompok perlakuan yaitu ekstrak daun belimbing wuluh dengan konsentrasi $40 \%, 60 \%, 80 \%, 100 \%$ dan kelompok kontrol yaitu amoksisilin sebagai kontrol positif dan aquades sebagai kontrol negatif. Pada kelompok perlakuan dilakukan pengukuran setelah hasil pengukuran tersebut kemudian dibandingkan dengan hasil kelompok kontrol.

\section{Jumlah pengulangan}

Jumlah sampel penelitian adalah 24 plate terdiri dari 6 kelompok perlakuan yang dilakukan pengulangan sebanyak 4 kali. Kelompok perlakuan yaitu 4 konsentrasi ekstrak daun belimbing wuluh, yaitu konsentrasi $40 \%$, 60\%, $80 \%$ dan $100 \%$, kelompok kontrol positif (amoksisilin $10 \mu \mathrm{g}$ ) dan kontrol negatif (aquades). Untuk pengulangan sampel rumus yang digunakan adalah rumus Federer.

Rumus Federer : (n-1) (t-1) $\geq 15$

$$
\begin{aligned}
& (\mathrm{n}-1)(\mathrm{t}-1) \quad \geq 15 \\
& \text { (n-1) (6-1) } \geq 15 \\
& \text { (n-1) (5) } \quad \geq 15 \\
& \text { (5n-5) } \quad \geq 15 \\
& \text { (5n) } \quad \geq 20 \\
& \text { n } \quad \geq 4
\end{aligned}
$$

ket : $\mathrm{n}$ : besar sampel

$$
\mathrm{t}: \text { jumlah kelompok }
$$

\section{ANALISA DATA}

Data hasil penelitian pengaruh ekstrak daun Belimbing wuluh terhadap pertumbuhan bakteri Staphylococcus aureus yang dilakukan dengan mengukur lebar zona jernih dianalisis dengan menggunakan program statistik komputer, untuk melihat efektivitas yang bermakna dari masing-masing cakram uji, yaitu cakram amoksisilin (kontrol positif), cakram aquadest (kontrol negatif), dan cakram yang mengandung ekstrak daun daun Belimbing wuluh dengan konsentrasi 40\%, 60\%, 80\%, dan 100\% Data pada penelitian ini diuji apakah berdistribusi normal atau tidak. Didapatkan data tidak berdistribusi normal tetapi homogeny. Maka data dianalisis dengan uji non parametrik yaitu uji Kruskal Wallis Test 
dan dilanjutkan dengan uji tanda beda Man Whitney Test.

\section{HASIL PENELITIAN}

Penelitian ini dilakukan di laboratorium Mikrobiologi Fakultas Kedokteran Universitas Muhammadiyah Sumatera Utara selama 8 hari.Untuk melakukan pengukuran dilakukan menggunakan alat jangka sorong dalam satuan millimeter.

Tabel 1. Hasil pengukuran efek antibiotik ekstrak daun belimbing wuluh (Averrhoa bilimbi L.) terhadap pertumbuhan bakteri Staphylococcus aureus.

\begin{tabular}{|c|c|c|c|c|c|c|}
\hline \multirow{3}{*}{ Pengulangan } & \multicolumn{6}{|c|}{$\begin{array}{l}\text { Diameter daya hambat pertumbuhan bakteri } \\
\text { Staphylococcus aureus (dalam satuan } \mathrm{mm} \text { ) }\end{array}$} \\
\hline & \multicolumn{4}{|c|}{$\begin{array}{l}\text { Ekstrak daun belimbing wuluh (Averrhoa } \\
\text { bilimbiL.) dengan konsentrasi }\end{array}$} & \multirow{2}{*}{ Kontrol + } & \multirow{2}{*}{ Kontrol - } \\
\hline & $40 \%$ & $60 \%$ & $80 \%$ & $100 \%$ & & \\
\hline Pengulangan 1 & 13,80 & 17,09 & 19,23 & 23,62 & 31,75 & 0 \\
\hline Pengulangan 2 & 13,78 & 17,15 & 18,22 & 22,30 & 34,00 & 0 \\
\hline Pengulangan 3 & 14,31 & 17,87 & 19,28 & 22,97 & 34,04 & 0 \\
\hline Pengulangan 4 & 14,51 & 17,38 & 18,20 & 23,10 & 34,01 & 0 \\
\hline
\end{tabular}

Pada tabel 1 didapati hasil bahwa pemberian berbagai konsentrasi ekstrak daun belimbing wuluh menunjukan zona bening yang dihasilkan. Pada konsentrasi ekstrak daun belimbing wuluh $40 \%$ pengulangan ke 4 diperoleh zona hambat tertinggi yaitu $14,51 \mathrm{~mm}$. Pada konsentrasi ekstrak daun belimbing wuluh $60 \%$ pengulangan ke 3 diperoleh zona hambat tertinggi yaitu $17,38 \mathrm{~mm}$. Pada konsentrasi ekstrak daun belimbing wuluh $80 \%$ pada pengulangan ke 3 diperoleh zona hambat tertinggi yaitu 19,28 mm. Pada konsentarsi ekstrak daun belimbing wuluh $100 \%$ pengulangan ke 1 diperoleh zona hambat tertinggi yaitu 23,65 mm. Pada kelompok kontrol positif yaitu amoksisilin pada pengulangan ke 3 diperoleh zona hambat tertinggi yaitu 34,04 mm, sedangkan pada kelompok negatif yaitu Aquabidest tidak ditemukan zona hambat.

Pada hasil analisis diperoleh nilai rata-rata Amoksisilin adalah 34,02 $\mathrm{mm}$ sedangkan standar deviasi diperoleh $0,03 \mathrm{~mm}$. Pada Aquabidest diperoleh rata-rata 0 dan standar deviasi 0 . Pada konsentrasi ekstrak daun Belimbing wuluh $40 \%$ diperoleh nilai rata-rata yaitu 14,07 $\mathrm{mm}$ dengan standar deviasi $0,39 \mathrm{~mm}$. Pada konsentrasi ekstrak daun Belimbing wuluh 60\% diperoleh nilai rata-rata yaitu $17,37 \mathrm{~mm}$ dengan standart deviasi $0,35 \mathrm{~mm}$. Pada konsentrasi ekstrak daun Belimbing wuluh $80 \%$ diperoleh nilai rata- rata yaitu $18,73 \mathrm{~mm}$ dengan standar deviasi $0,60 \mathrm{~mm}$. Pada konsentrasi ekstrak daun Belimbing wuluh $100 \%$ diperoleh nilai rata-rata yaitu $22,90 \mathrm{~mm}$ dengan standar deviasi 0,54 mm. Hasil Uji Kruskall-Wallis diperoleh $\mathrm{p}<0,05$ yang membuktikan bahwa tiap perlakuan yang diujikan terdapat perbedaan zona hambat yang dihasilkan pada konsentrasi ekstrak daun Belimbing wuluh konsentrasi $40 \%, 60 \%, 80 \%$ dan $100 \%$ serta kelompok kontrol positif (cakram Amoksisilin) dan cakram kontrol negatif (Aquadest).

\section{PEMBAHASAN}

Dari hasil penelitian uji daya hambat ekstrak daun belimbing wuluh (Averrhoa bilimbi L.) terhadap bakteri Staphylococcus aureus secara in vitro terlihat perbedaan nilai yang diperoleh dengan masing-masing konsentrasi $40 \%, 60 \%, 80 \%, 100 \%$. Pada penelitian ini bahwa ekstrak daun belimbing wuluh dapat menghambat pertumbuhan bakteri Staphylococcus aureus.

Pada penelitian yang dilakukan oleh Destriani, didapatkan 14 isolat bakteri endofitik dari tumbuhan belimbing wuluh (Averrhoa bilimbi L.) yang menghasilkan antibiotika, 6 isolat bakteri memiliki zona bening terhadap E. coli, 14 isolat bakteri 
terhadap Staphylococcus aureus dan 6 isolat bakteri terhadap E. coli dan Staphylococcus aureus. Hal ini menunjukan tumbuhan belimbing wuluh dapat menghambat pertumbuhan bakteri. ${ }^{9}$ Menurut penelitian sebelumnya yang di lakukan Zakaria menyatakan ekstrak belimbing wuluh dengan menngunakan teknik cakram difusi terdapat adanya daya hambat pada beberapa bakteri gram positif dan negatif. ${ }^{10}$

Berdasarkan penelitian lain yang dilakukan Estri noviana, menyebutkan bahwa semakin tinggi konsentrasi ekstrak yang diberikan maka semakin baik efek yang dihasilkan. ${ }^{11} \mathrm{Hal}$ ini juga sesuai dengan penelitian yang dilakukan oleh Hidayat dan kuvaini juga menunjukkan bahwa semakin tinggi konsentrasi ekstrak daun surian akan menghasilkan daya hambat yang semakin baik pula. ${ }^{12}$

Menurut beberapa penelitian sebelumnya ada beberapa faktor yang mempengaruhi hasil uji daya hambat yaitu kandungan zat antibakteri pada belimbing wuluh. Kandungan antibakteri tersebut adalah flavonoid, tripenoid, tanin, dan saponin. ${ }^{13}$

Berdasarkan hasil penelitian ini didapatkan efek antibiotik ekstrak daun belimbing wuluh dengan konsentrasi 40\%, 60\%, 80\%, dan 100\% terhadap pertumbuhan bakteri Staphylococcus aureus, namun efek tersebut lebih kecil jika dibandingkan dengan efek amoksisilin, karena dengan konsentrasi $40 \%$, 60\%, 80\%, dan $100 \%$, terdapat daya hambat ekstrak daun belimbing wuluh, dimana semakin besar konsentrasi ekstrak daun belimbing wuluh, maka daya hambat ekstrak daun belimbing wuluh terhadap pertumbuhan bakteri Staphylococcus aureus semakin baik.

\section{KESIMPULAN}

Ekstrak daun belimbing wuluh memiliki efek antibiotik terhadap pertumbuhan bakteri Staphylococcus aureus.

\section{DAFTAR PUSTAKA}

1. Mutadi, Ambarwati R YR. 2012. Aktivitas antibakteri etanol dan fraksi kulit batang belimbing wuluh (Averrhoa bilimbi L.) terhadap bakteri Kiebsiella pneumoneae dan Staphylococcus epidermidis. Univ Muhammadiyah Surakarta.

2. Mandala B, Wilkins E, Dunbar E M-WR. 2007..Lecture Notes Penyakit Infeksi. . EGC. Jakarta

3. WHO. 2012.Infection Diseases are the Biggest Killer of the Young.

4. Asri RC, Rasyid R. 2014. Identifikasi MRSA pada Diafragma Stetoskop di Ruang Rawat Inap dan HCU Bagian Penyakit Dalam.;6(2):239-244.

5. RI M. 2016. Peraturan Menteri Kesehatan Republik Indonesia. Peraturan Menteri Kesehatan NO 72

TAHUN 2016.:4.

6. Cahyaningsih I, Wiedyaningsih C, Kristina SA. 2013. Effect of Education on the Level of Community Knowledge about Analgesic in Cangkringan, Sleman Regency, Yogyakarta, Mutiara Med.;13(2):98-104.

7. Abrar, B. 2012. Aktivitas antibakteri ekstrak etanol daun belimbing wuluh (Averrhoa bilimbi L.) terhadap mencit diabetes.

8. Ayu P, Devi C, Zubaidah E, Sriherfyna FH. 2016. Karakteristik fisik- kimia dan aktivitas antibakteri ekstrak daun belimbing wuluh ( Averrhoa bilimbi L .) Physical- Chemistry Characteristics and Antibacterial 
Activity of Bilimbi ( Averrhoa bilimbi L .) Leaves Extract.;4(1):400-40

9. Desriani D, Safira UM, Bintang M, Rivai A, Lisdiyanti $\quad$ P. 2014. Isolasi dan karakterisasi bakteri endofit dari tanaman binahong dan katepeng china. Jurnal Kesehatan Andalas. May 1;32

10. Zakaria A, Zaiton H,dkk. 2015. In vitro antibacterial activity of Averrhoa bilimbi L. Leaves and fruit extract. Malaysia. Fakultas farmasi Universitas teknologi Mara. Internasional journal of tropical medicine : Medwell journal

11. Noviana E. 2011. Uji potensi Ekstrak daun Suren (Toona sureni) sebagai insektisida ulat grayak pada tanaman kedelai. Surakarta: Fakultas pertanian Universitas sebelas maret.

12. Hidayat $\mathrm{Y}$ dan Kuvaini A, 2005. Keefektifan ekstrak daun belimbing wuluh (Averrhoa bilimbi L.)) dalam pengendalian larva boktor (Xystrocera festiva Fascoe). Agrikultura. Agustus;16(2).

13. Datu T, Mita N RR. 2015.Aktivitas antibakteri saribuah belimbing wuluh (Averrhoa bilimbi L.) terhadap Psudomonans aeruginosa. Kalimantan: Fakultas Farmasi Universitas Mulawarman. 